\title{
Printing Medical Knowledge
}

\section{Vernacular Genres, Reception and Dissemination}

\author{
Sabrina Minuzzi | ORCID: 0000-0001-8960-7690 \\ Ca' Foscari University of Venice, Venice, Italy \\ sabrina.minuzzi@unive.it
}

The idea for this special issue arose during the final conference of the Dutchfunded EDPOP Project (European Dimension of Popular Print) led by Jeroen Salman. ${ }^{1}$ Starting from a few of the presentations delivered during the session Popular medical books in Europe ${ }^{2}$ we thought of creating a small volume at the intersection of the history of medicine and the history of books. We decided to leave by the wayside the adjective popular, which always needs appropriate distinctions and justifications, and has been widely discussed by scholars since the last century. ${ }^{3}$ We have, however, preserved some derived forms that do not suffer from the same ambiguity due to the context in which they are placed.

The object of investigation is the medical knowledge embodied in widely spread vernacular genres, namely across different social groups and literacy levels: from the illustrated book on materia medica to the encyclopaedic handbook, from the recipe collection 'for the poor' to the few-leaves regimen sanitatis and plague tracts, from pamphlets/booklets to flyleaves with short poems sometimes intended for oral performance. It is a production of a varied type, which only partly falls within the sphere of cheap print and for which 'vernacular' is not a category pertaining solely to language — in itself not always widely

1 Utrecht University, on the project see https://edpop.wp.hum.uu.nl/ (this and the following websites were accessed on 31 March 2021).

2 Conference flyer in https://edpop.wp.hum.uu.nl/international-conference-the-european-di mensions-of-popular-print-culture/.

3 The problematic nature of the definition of popular is explored by Bob Scribner, "Is a History of a Popular Culture possible?," History of European Ideas 10 (1989): 175-191; and, in a comparative European key, in Roger Chartier and Hans Jürgen Lüsebrink, eds., Colportage et lecture populaire. Imprimés de large circulation en Europe, XVIe-XIXe siècles (Paris: Imec-éditions, 1996). A review of the stages of the debate and further reflections are in the introduction by Mario Infelise and Lodovica Braida to Libri per tutti. Generi editoriali di larga circolazione tra antico regime ed età contemporanea (Torino: Utet, 2010), 3-19. 
accessible despite being vernacular language - but to the kind of knowledge that this production conveys. ${ }^{4}$ Rather, the common denominator is the fact that these publications all disseminate, to varying degrees, practical knowledge capable of arousing and satisfying the curiosity of - and, in a few cases, entertaining — a broader public than just experts, that is, also of non-medical professionals, ranging from scholars to the common person who may have had little or no literacy. ${ }^{5} \mathrm{~A}$ practical production which, in most cases, also conveyed and taught notions of theoretical medicine.

Book history has provided some methodologies that may be helpful to explore the production, dissemination and reception of medical-scientific knowledge. In several of the contributions attention has been paid to the material forms in which the texts are embodied, crucial for outlining the intended reader and the ways in which the publication was intended to be read: format, illustrations, organisation and distribution of the text, indexes, statements of intent in dedicatory epistles/prefaces, etc. Moreover, the examination of the traces that early modern readers left on these materialised texts has helped to piece together the profile of the actual readers of the book, sometimes despite the intentions of their 'producers'. 6

4 Joad Raymond, ed., The Oxford History of Popular Print Culture. Cheap Print in Britain and Ireland to 1660 (Oxford: OUP, 2011). On the concept of 'vernacularisation' see the opening of Sandra Cavallo's article.

5 As to literacy levels, see also Heidi Braymann Hackel, "Rhetorics and Practices of Illiteracy or the Marketing of Illiteracy," in Reading and Literacy in the Middle Ages and Renaissance, ed. Ian Frederick Moulton (Turnhout, Belgium: Brepols, 2004), 169-183.

6 Theoretical foundations in the elaboration of such methodologies have been the work by Lucien Febvre and Henri-Jean Martin, L'apparition du livre (1958; Paris: Albin Michel, 1999) born in the wake of the Annales, which has given the book and its history the due economic and social as well as cultural relevance; the German studies on the history of reception (Rezeptiongeschichte) during the 1970s, and, in the 1980s, the works by Donald F. Mackenzie who enriched with a socio-historical dimension the philological-textual approach typical of the English tradition. He inaugurated the so-called 'sociology of texts' by expanding the concept of text to non-verbal devices/signs and with investigations on the material features of the book for reconstructing their social impact in the production, transmission and reception of texts (Donald F. Mackenzie, Bibliography and the Sociology of Texts [London: The British Library, 1986]). A further milestone in the elaboration of the concept and functions of the paratext was Gérard Genette, Seuils (Paris: Editions du Seuil, 1987), English translation in Paratexts. Thresholds of interpretation (Cambridge: CUP, 1997). See also numerous contributions that have appeared over the years in the journal Histoire et civilisation du livre. Revue internationale and the Dossier no. 16 (2020): Christine Bénévent, Emmanuelle Chapron, and Jean-Dominique Mellot, eds., Où va l'histoire du livre? Bilans et chantiers dans le sillage d'Henri-Jean Martin (1924-2007). 
Since the late 2oth century a thriving scholarly literature of national scope on paratexts and marginalia has blossomed, but nothing about the early modern medical book of wide circulation. ${ }^{7}$ Printing Medical Knowledge is just a first piece in the mosaic that we would like to make available through such surveys on European medical literature-especially the little studied ones-so as to provide new touchstones for further research.

The first essay offers a genre-based mapping of printed medical-scientific production in 15th-century Europe, a period still often neglected by historians of medicine. In regard to some long-lasting titles in the Italian vernacular, the contribution explores the evolution of their material forms in the 16th and 17th centuries in the direction of a more enjoyable and thus more widespread reading, far from being merely professional. Drawing on recently created databases that in a few years' time will allow for statistical elaborations also of the traces left by readers' use, the essay suggests paths of investigation that simultaneously take into account the manuscript and the printed tradition together with patterns of consumption of texts.

Sandra Cavallo significantly expands our understanding of vernacular medical advice books in early modern Italy by interpreting these works within the context of the 'vernacularization' of science. She reflects on the various typologies of books that fall within this broader genre and shows how many of them flourished from the earliest days of printing, thus undermining some scholarly convictions like the one that the most common form of medical advice literature printed in Italy (i.e. recipe collections) enjoyed success only from the 1550s onwards-with all the relevant cultural repercussions. Fully assimilating the most up-to-date acquisitions in the history of books, she focuses on some key features that had a bearing on making a medical advice book appealing to a large audience: not only the vernacular but also the text layout, as well as the contents and the use (or abuse) of authorship. The contextual analysis of annotated exemplars illustrating these various aspects functional to the dissemination of medical knowledge proves their extraordinarily wide reception.

7 Very promising research on this type of medical book is Mary Fissell's ongoing work on Aristotle's Masterpiece, the early-modern title on sex and reproduction that was an Anglo-America's best-seller between 1684 and the 20 th century. Fissell focuses on ordinary readership by examining hundreds of annotated copies, and on the ways in which the book was tweaked by printers and publishers to adapt it to changing markets. A collective effort on the scientific book produced the miscellaneous volume Marina Frasca-Spada and Nick Jardine, eds., Books and the Sciences in History (Cambridge: CUP, 2000); in regards with scientific manuscripts, Danielle Jacquart and Charles Burnett, eds., Scientia in Margine. Études sur les Marginalia dans les manuscrits scientifiques du Moyen Âge à la Renaissance (Geneva: Librairie Droz, 2005). 
Elma Brenner shows, by means of a late 15th-century case-study from Normandy, how also a thin plague-tract ostensibly addressed to the poor and seemingly designed to be a broadly accessible reading, enjoyed only a professional circulation among lay and religious local practitioners of middling-sort status. This is also a warning not to make facile equations between vernacular languages and the capacity for broad social penetration. The analysis of a few miscellaneous volumes assembled with printed and manuscript texts by early owners (Sammelbände), highlights the circulation of many titles of undeniable popular interest among the professionals.

Tessa Storey has focused on sources that are in themselves irrefutable evidence for the transmission of vernacular medical knowledge via entertainment among the most diverse levels in society: cheap songs printed in Italy between $155^{\circ}$ and 1650 , sung in the streets and listened both by the literate and illiterate or semi-literate, males and females simply passing by. Their authors and performance techniques are well investigated by scholars under the social profile, but Tessa offers, thanks to her expertise based on previous works, a subtle analysis of the actual medical contents delivered through the songs mocking medical advice for healthy living (regimina). Albeit devoid of references to underlying theoretical principles, these songs reflected, while distorting them, contemporary medical opinions and controversies on foodstuffs and living habits that can also be detected in the treatises of the day. Tessa cleverly introduces the category of 'oral marginalia' to represent the bystanders' feedback that would have helped the cantastorie to shape new future compositions.

Andrea van Leerdam investigates the dissemination of materia medica knowledge through the genre of the voluminous illustrated printed herbals. Her case study of the Dutch Den groten herbarius met al sijn figueren ("The great herbal with all its figures") published six times between 1514 and 1547, provides some new and surprising findings that can be applied to the whole genre of printed herbals between the dawns of printing and the whole of the 16th century. Andrea aptly examines both the publishing strategies implemented through the material realisation of the editions, and the wide array of actual readers of 27 surviving copies of Den groten herbarius.

Bruno Barreiros and Palmira Fontes da Costa offer a novel overview of printed and manuscript production in Portugal in the 17th and early 18th centuries, little known to international scholars beyond the famous handful of authors who dealt with exotic materia medica. Once they had identified the peculiarity of Portuguese print production of a medical-scientific nature in the genres miscellany, they distinguish between three main streams: compendiums or collections of medical remedies and recipes, books of common errors, large format works on materia medica. We learn that the Portuguese literature 
on popular errors dealt almost exclusively with materia medica, and that the manuscript production, which was always very lively in Portugal partly because it was able to circumvent the meshes of censorship, surpassed the printed production in terms of originality.

This special issue concludes with Barbara Di Gennaro Splendore's essay, which spans three centuries of printed production following the path of a compound medicine of long duration and extremely wide circulation: theriac, an ancient antidote dating from the ist century в $\mathrm{C}$. In her recent research she has identified over 5oo theriac-related titles printed across Europe between 1497 and 1800 . She admirably processes her data both quantitatively and qualitatively, outlining the profile of different genres changing over the centuries and recognising on apothecary publications - recipes, virtues, and celebrationsthe circumstances of the greatest popularisation and dissemination of scholarly medical knowledge among different social and professional groups, while propelling the remedy's commercial success.

I wish to thank the authors who contributed to this Special Issue for their efforts in producing their articles during the current pandemic period that has seriously affected everyone, and has made research work particularly arduous by limiting access to libraries and archives.

A special thanks to the Nuncius editorial staff-Elena Canadelli editor-inchief, Marta Stefani and Luca Tonetti-for their professionalism and generous support that have made it possible to greatly improve this Special Issue. 